\section{EMBRYRIDDLE}

Aeronautical University

SCHOLARLY COMMONS

\section{Journal of Aviation/Aerospace}

Education \& Research

Volume 12

Number 1 JAAER Fall 2002

Article 9

Fall 2002

\title{
The Orteig Prize
}

Tim Brady

bradyt@erau.edu

Follow this and additional works at: https://commons.erau.edu/jaaer

\section{Scholarly Commons Citation}

Brady, T. (2002). The Orteig Prize. Journal of Aviation/Aerospace Education \& Research, 12(1).

https://doi.org/10.15394/jaaer.2002.1595

This Article is brought to you for free and open access by the Journals at Scholarly Commons. It has been accepted for inclusion in Journal of Aviation/Aerospace Education \& Research by an authorized administrator of Scholarly Commons. For more information, please contact commons@erau.edu. 


\title{
THE ORTEIG PRIZE
}

\author{
Tim Brady
}

\author{
Science, freedom, beauty, adventure: \\ What more could you ask of life? \\ Aviation combined all of the elements $I$ loved. \\ There was science in each curve of an airfoil. . \\ There was freedom in the unlimited horizon. . . \\ A pilot was surrounded by beauty of earth and sky... \\ Adventure lay in each puff of wind. ${ }^{.}$ \\ Charles A. Lindbergh
}

It can be reasonably argued that, apart from the Wright brothers' epic flight of 1903, which ushered the world into aviation, the single most important flight made in the twentieth century was the transatlantic flight made by Charles A. Lindbergh in May 1927.

The economic impact of this solo flight was astonishing. For example, in the three-year period following the flight, the number of passengers carried annually by air increased by $443 \%$ (from 8,679 in 1927 to 384,506 in 1930). The stock of the company that made the engine for Lindbergh's Spirit of St. Louis airplane, the Wright Company, jumped from \$25 per share in May of 1927 to \$245 per share in December of 1928 (Brown, 89). Other companies reaped the benefits also. An investor who bought 200 shares of stock in the aircraft engine company Pratt and Whitney in 1924 for 20 cents a share, saw the stock split several times so that by November 1928 the original 200 shares was now 16,000 shares. The stock split again so that by January 1929 it became 34,720 shares worth a whopping $\$ 5,555,200$. Not bad for a forty dollar investment (Fruenthal, 95-96).

The economic influence of the Lindbergh flight was profound across the aviation spectrum. The number of pilot licenses quadrupled within a few months after the flight and kept on climbing. "An aircraft manufacturing industry that had produced 302 airplanes in 1921 produced 5,000 in 1928 and 7,000 in 1929" (Brady, 144). The number of airline employees increased by $250 \%$ from 1929 to 1932. All of this occurred despite a ruptured economy whose GNP had plummeted $45 \%$ in a raging depression. The average annual income dropped from \$1,350 in 1929 to $\$ 754$ in 1933 . About the only economic indicators that weren't falling like a stone were the ones that weren't supposed to in a depression: the unemployment rate jumped from $3 \%$ to $24 \%$ from 1929 to 1933 and the suicide rate also rose dramatically.

Many blamed the depression on President Herbert Hoover as homeless sites called "Hoovervilles" sprung up everywhere. Those same people gave credit to Lindbergh for fueling the boom that was simultaneously occurring in aviation and which was going against the grain of the depression.

While the Lindbergh legacy is well known, what is less well known is the reason the flight occurred at all and the drama of the international competition surrounding the flight. It was to compete for the Orteig Prize that Lindbergh made the now-famous flight in his Ryan aircraft, the Spirit of St. Louis. There were others were in the chase also: Frenchman pilot and war hero Rene Fonck in a trimotored Sikorsky S-35, American Admiral (then Commander) Richard Byrd in a tri-motored Fokker, Navy pilots Lieutenant Commander Noel Davis and Lieutenant Stanton Wooster in a tri-motored Keystone Pathfinder,

${ }^{1}$ (Lindbergh, The Spirit of St. Louis, 1953, p. 261) 
French war hero Charles Nungesser and his companion flier Francois Coli in a single-engine Levasseur PL-8, and Americans Clarence Chamberlin and Bert Acosta in a single-engine Bellanca.

The goal of this article is to describe the efforts of the Orteig Prize competitors using as a departure for discussion the airplane used by each group. But first, the Orteig Prize will be described followed by a matrix showing the chronology of the competitors.

\section{Raymond Orteig.}

The Orteig Prize was offered by Raymond Orteig, a New York hotel owner who was born in France but had lived in the U.S. since 1882. He had started out in the hotel business as a waiter and had risen to own two prominent New York hotels, the Hotel Brevoort and the Hotel Lafayette. Both had been great centers for the French in New York both during and immediately after World War I. Orteig had become interested in aviation as a result of having met a great many French fliers during and after the Great War.

To establish the prize, Orteig made the offer to the offices of the Aero Club of America in the following letter ("Puts Up \$25,000 for Paris Flight," The N. Y. Times, May, 30, 1919):

New York, May 22, 1919

Aero Club of America,

201 Madison Avenue, New York Center

Gentlemen:

As a stimulus to the courageous aviators, I desire to offer through the auspices and regulations of the Aero Club of America, a prize of $\$ 25,000$ to the first aviator of any allied country crossing the Atlantic in one flight, from Paris to New York or New York to Paris, all other details in your care.

Yours Very Sincerely

Raymond Orteig

Orteig's offer was for a period of five years and went unanswered. In June of 1925, he renewed the Prize with some modifications. The award would be given to the first aviator without regard to country of origin (the term "Allied" was removed) who crossed the Atlantic "without stop" in "a land or water aircraft (heavier-than-air)." This offer stimulated aviation enthusiasts on both sides of the Atlantic (Jablonski, p. 74), and the race was on. 


\section{Chronology of the Primary Orteig Prize Competitors}

\begin{tabular}{|c|c|c|c|c|c|}
\hline Date & Crew & Aircraft Type & Engines & Event & Remarks \\
\hline $\begin{array}{l}\text { September 21, } \\
1926\end{array}$ & $\begin{array}{l}\text { Fonck \& } \\
\text { others }\end{array}$ & $\begin{array}{l}\text { Sikorsky } \\
\text { S-35 } \\
\text { Sesquiplane }\end{array}$ & $\begin{array}{l}\quad 3 \\
\text { French } \\
\text { Jupiter } \\
\text { Radials } \\
\end{array}$ & $\begin{array}{l}\text { Crashed on } \\
\text { takeoff }\end{array}$ & $\begin{array}{l}\text { Aircraft destroyed - Two } \\
\text { of the crew died }\end{array}$ \\
\hline April 16, 1927 & $\begin{array}{l}\text { Byrd \& } \\
\text { others }\end{array}$ & $\begin{array}{l}\text { Fokker } \\
\text { Monoplane }\end{array}$ & \begin{tabular}{l}
\multicolumn{1}{c}{3} \\
American \\
Wright \\
Whirlwind \\
s
\end{tabular} & $\begin{array}{l}\text { Damaged } \\
\text { on landing }\end{array}$ & $\begin{array}{l}\text { All crewmembers injured; } \\
\text { aircraft significantly } \\
\text { damaged }\end{array}$ \\
\hline April 24, 1927 & $\begin{array}{l}\text { Chamberlin } \\
\& \text { others }\end{array}$ & $\begin{array}{l}\text { Bellanca } \\
\text { Monoplane }\end{array}$ & $\begin{array}{l}\quad 1 \\
\text { American } \\
\text { Wright } \\
\text { Whirlwind }\end{array}$ & $\begin{array}{l}\text { Damaged } \\
\text { on landing }\end{array}$ & $\begin{array}{l}\text { Minor damage to landing } \\
\text { gear }\end{array}$ \\
\hline April 26, 1927 & $\begin{array}{l}\text { Davis \& } \\
\text { Wooster }\end{array}$ & $\begin{array}{l}\text { Keystone } \\
\text { Pathfinder } \\
\text { Biwing }\end{array}$ & \begin{tabular}{l}
\multicolumn{1}{c}{3} \\
American \\
Wright \\
Whirlwind \\
s \\
\end{tabular} & $\begin{array}{l}\text { Crashed } \\
\text { shortly } \\
\text { after } \\
\text { takeoff }\end{array}$ & $\begin{array}{l}\text { Aircraft nosed over - Both } \\
\text { pilots died }\end{array}$ \\
\hline May 8, 1927 & $\begin{array}{l}\text { Nungesser } \\
\& \text { Coli }\end{array}$ & $\begin{array}{l}\text { Levasseur } \\
\text { PL-8 Biwing }\end{array}$ & \begin{tabular}{|l|}
\multicolumn{1}{c}{1} \\
Lorraine- \\
Dietrich \\
\end{tabular} & $\begin{array}{l}\text { Disappeare } \\
\text { d en route }\end{array}$ & $\begin{array}{l}\text { Both pilots missing - } \\
\text { presumably dead }\end{array}$ \\
\hline May 20, 1927 & Lindbergh & $\begin{array}{l}\text { Ryan } \\
\text { Monoplane }\end{array}$ & \begin{tabular}{l}
\multicolumn{1}{c}{1} \\
American \\
Wright \\
Whirlwind
\end{tabular} & Successful & \\
\hline
\end{tabular}

The Sikorsky S-35

Captain Rene Fonck, France's top ace of World War I, decided to put a team together to try for the Orteig Prize. His plan was to have the airplane built in America and to make the crossing from West to East to take advantage of the prevailing winds. He visited several companies in the U.S. and decided on the Sikorsky Aero Engineering Corporation of Long Island, New York.

Sikorsky's reputation for building reliable multiengine aircraft was well known throughout the aviation world. In fact he had built the world's first four-engine airplane at his facility in Kiev, Russia. Several of Sikorsky's multi-engine airplanes saw service in World War I with the Russian military and acquitted themselves quite well. Of the seventy-three four-engine bombers built by Sikorsky, only one was shot down over the front. Others came back shot up, tattered, and torn, but they came back. "One bomber, torn by shrapnel and with three engines damaged, limped back to a Russian field with its commander unconscious and its co-pilot at the controls. Upon landing, the plane's right wing fell to the ground. The load wires had been shot away and only the supporting air pressure of the flight had kept the wings in place" (Delear, Sikorsky, 1992, p. 77).

After the Russian revolution of 1917 the now-outof-work Igor Sikorsky emigrated first to France then to the United States arriving in the Spring of 1919. In an aviation environment overloaded by war-surplus airplanes, Sikorsky struggled through several years in his attempt to set up an aircraft manufacturing plant. Finally he established a company first in Manhattan then in Long Island. Staffed mostly by Russian immigrants, the plant began to turn out 
reliable products.

When Captain Fonck discussed an airplane with Sikorsky, he first defined it as a twin-engine airplane. But as Sikorsky began to study the mission in detail, he determined that a three-engine airplane was a better option. In September, 1926 the new Sikorsky airplane, named the S-35 (the $35^{\text {th }}$ model of aircraft built by Sikorsky beginning with his Russian days), was rolled out. While the S-35 might well have been Sikorsky's "greatest triumph," it became the "most disappointing episode" of his life (Delear, Sikorsky, 1992, pp. 113, 114).

The airplane, a sesquiplane, was "huge, elegant, efficient, and modern looking" (Delear, Sikorsky, 1992, p. 114). It was powered by three French-built Gnome-Rhone Jupiter 9A, air-cooled, nine-cylinder, radial engines each of which developed 420 horsepower. The S-35 was described as an all-metal aircraft built of Duralumin and steel. It had a gross weight of 24,200 pounds with a top wingspan of 101 feet and a lower wingspan of 76 feet (thus the description, sesquiplane, one wing considerably shorter than the other). The airplane had a fuselage length of $\mathbf{4 4}$ feet ("On the Proposed," Aviation, August, 1926, pp. 318, 319).

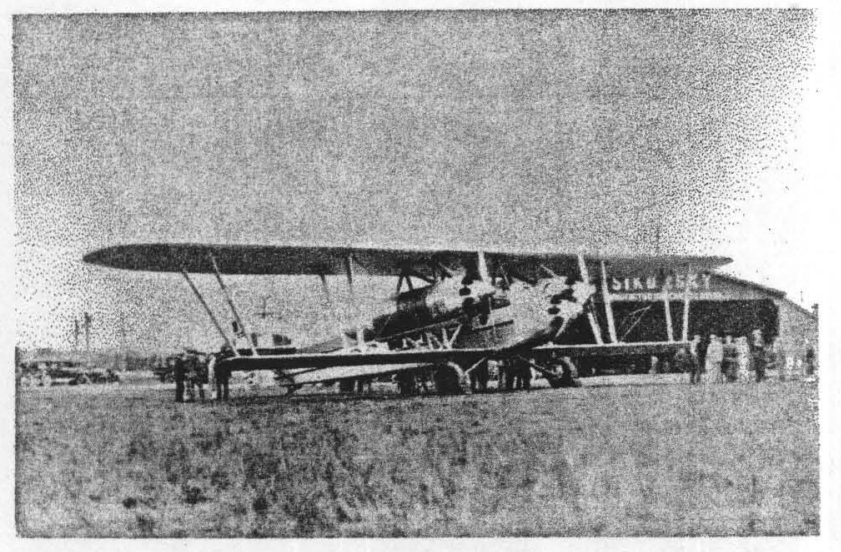

\section{The Sikorsky S-35}

photograph copyright: Igor I. Sikorsky Historical Archives; Stratford, CT 06615

An interior decorator was called in by Fonck to turn the cabin space of the S-35 into a tastefully furnished drawing room with a color scheme of red, gold, and silver. The ceiling was done in cream and the walls were decorated with panels of brown Spanish leather and mahogany. The panels at the ends of the cabin were machine-planed aluminum. Each of the eight cabin windows was made of bullet-proof glass. Under each window was a small mahogany table. Elsewhere in the cabin there were wicker chairs and a divan which could be converted into a bed. Electric dome lights were installed in the ceiling ("Fonck's Plane Beautified," N.Y. Times, July 28,1926 ).

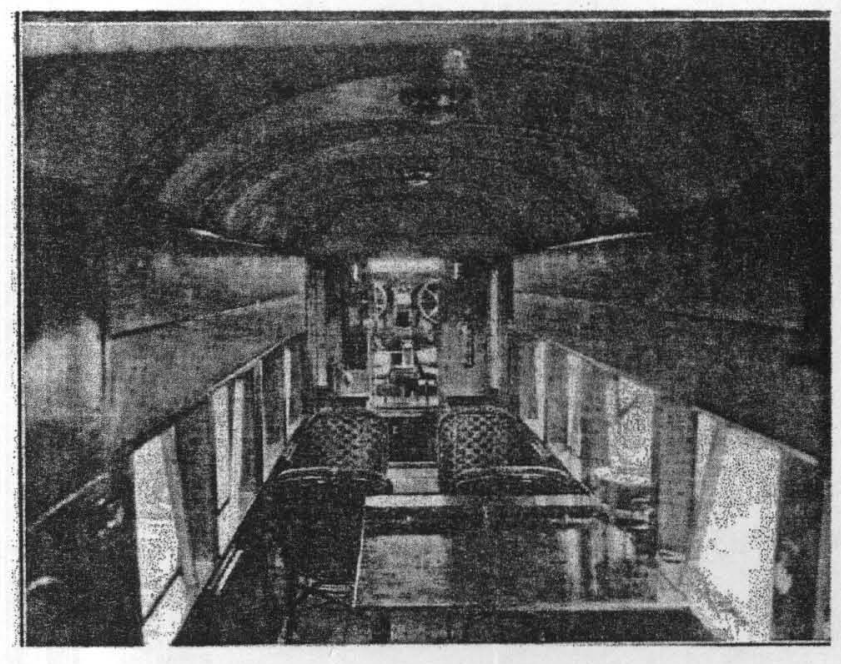

The interior cabin of the Sikorsky S-35.

photograph: Aircraft Year Book, 1927, Aeronautical Chamber of Commerce

The flight to Paris was going to be made in style. It was even planned that a hot dinner would be prepared by the chefs at the Hotel McAlpin and placed in vacuum containers to be served on arrival at Paris to the flight's sponsor. "The menu included Manhattan clam chowder, Baltimore Terrapin, roast Long Island duck and Vermont turkey" ("Fonck's Plane to Carry," N.Y. Times, August 16, 1926).

Neither the menu nor the plush cabin are important in and of themselves, rather they point to the notion that saving weight did not seem to be a high priority in the Fonck camp.

The aircraft had gone thorough a series of flight tests during which it performed beautifully. The maximum weight for any of the tests was 20,000 pounds. Sikorsky was not satisfied that a sufficient number of tests had been conducted prior to the trans-Atlantic attempt but the 
Sikorsky company was under pressure to accept advertising arrangements. Additionally, the sponsors of the flight wanted the tests speeded up because the end of the good flying weather was approaching. "The circumstances were unfortunate," Sikorsky recalled many years later. "We were broke, we had no money, and I had to accept advertising and publicity tie-ins with oil companies. I hated it and I fought it, but in the end, I had to give in" (Delear, Sikorsky, 1992, p. 119).

On the day of the attempted Orteig flight, September 21, 1926, the aircraft was fully loaded with 2,380 gallons of fuel ("Fonck Plane Burns," N.Y. Times, September 22, 1926). The aviation gasoline was distributed in two tanks built into the engine nacelles for the wingmounted engines and in extra tanks in the cabin. Once the four crewmembers were aboard along with all of the supplies, equipment, and luxuries, the airplane weighed more than 28,000 pounds. Extra wheels to support the added weight had been attached. These were designed to be jettisoned as soon as the airplane was safely airborne.

The S-35 started down the 5,580 feet of runway, which was actually more of a prepared pathway which was crossed several times by intersecting and bumpy roads and which was lined on both sides by people and cars. On a slight knoll, Sikorsky watched with some trepidation. The wind, which had been calm, was now blowing in the direction of takeoff, a unneeded tailwind (Delear, Sikorsky, 1992 , p. 120). About 900 feet into its takeoff roll the airplane crossed one of the bumps caused by a road that intersected the runway. "The plane bounced. . .and an auxiliary wheel tore loose, spun around and leaped into the air. The plane lurched to the left and with a terrific effort, Fonck straightened it out again. . The wheel under the tail skid made a wild leap into the air and the skid dropped to the ground. One of these wheels struck the lower part of the left rudder and broke it loose so that it fell to the field about two thirds of the way down the runway. . then the plane began to shed parts as if it was a rickety old automobile coming to pieces" ("Fonck Plane Burns," N.Y. Times, September 22, 1926).

Part of the tail was dragging on the ground and, unfortunately, the airplane was not equipped with wheel brakes. Fonck was out of choices. He couldn't abort, couldn't turn, and it was unlikely the airplane was going to fly. "There was a mob of people to consider: if he turned, the plane would plow through them; if he cut his engines he would loose control and accomplish the same thing.
There was nothing else to do - keep going" (Jablonski, p. 82). The airplane sailed off the end of the runway and piled up at the base of a small rise. Within seconds it burst into flames. Fonck and his co-pilot/navigator Lieutenant Lawrence Curtain, a U.S. Navy pilot, survived the crash with hardly a scratch. The radio operator, Charles Clavier, who was returning to France and the Sikorsky mechanic, Jacob Islamoff, were knocked unconscious and perished in the resulting fire. The aircraft was completely demolished.

There can be little doubt that the airplane was overloaded. Lindbergh was to write later about his thoughts in 1926 concerning the Sikorsky, "A plane that's got to break the world's record for nonstop flying should be stripped of every excess ounce of weight" (Lindbergh, Spirit of St. Louis, 1953, p. 17). Igor Sikorsky also supported this conclusion. He and others believed that the flight should have been made with just a pilot and copilot/navigator. "The other two were not needed," Sikorsky said. "They were extra weight" (Delear, Sikorsky, 1992, p. 121).

The Orteig prize had claimed its first two victims.

\section{The Fokker "America"}

The name of Richard E. Byrd's airplane, "America" had ties to two previous aircraft by the same name, each designed to fly the Atlantic. The common denominator was Rodman Wanamaker, a wealthy department store heir from Philadelphia who believed that airplanes could conquer the Atlantic. He was a visionary who wanted to do his part to foster the idea of transatlantic flight. Wanamaker's first America, which was wrecked in a storm, was the largest airplane built in the United States to that time ("A Salute," p. 3). Next, he contracted with the Curtiss company to build the second America, a threeengine seaplane. Testing of the airplane was completed in the summer of 1914, but two weeks later an archduke and his wife were assassinated at someplace in Europe called Sarajevo and within two months the world was as war. Wanamaker and Curtiss' plans for flying the America across the Atlantic were swept up in the frenzy of conflict (Jablonski, p. 2). 


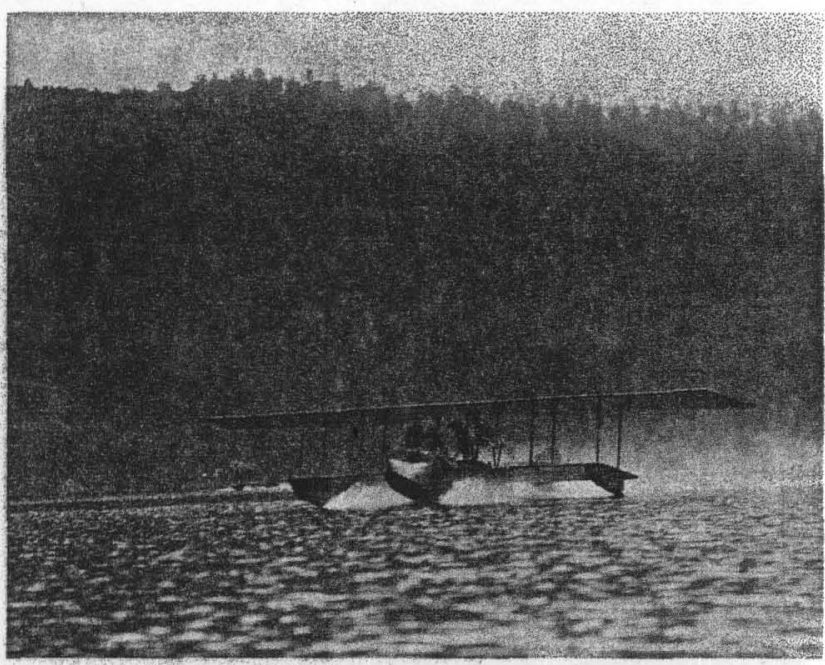

Curtiss-Wanamaker Model H “America” Flying Boat- Flight testing in Keuka Lake 1914 photograph copyright: Antique Aviation Art Gallery

Byrd got the attention of Wanamaker after his successful flight to the North Pole in 1926 in a three engine aircraft built by Fokker. Pursuing anunfulfilled dream, Wanamaker agreed to back Byrd's venture to fly the Atlantic. The new America was ordered from the Atlantic Aircraft Corporation, the American branch of the Dutch Fokker Company ("Crack Navy Pilots," N.Y. Times, April 10, 1927).

Richard E. Byrd was descended from an old Virginia family, themselves descendants of the French King Henry of Navarre (Henry IV) (Murphy, p. 17). The Byrd family had a history of distinguished service to Virginia; Harry Flood Byrd, Richard's brother, was the Governor of Virginia. Richard Byrd had attended the Naval Academy and had seen active service with the Navy but was retired from active service for disability in 1916 when he drove a nail through his foot. Though nominally retired, he continued in active service and in 1922 through a special act of Congress, he was promoted to Lieutenant Commander, "a rank he would have attained if he had not been in nominal retirement" "Crack Navy Pilots," N.Y. Times, April 10, 1927). Not a pilot, Byrd's expertise lay in his organizational skills and in his navigational expertise (Jablonski, p. 85). Earlier in his career, Byrd was chosen by the Navy to organize the navigation work for the crossing of the Atlantic by Navy NC flying-boat aircraft in 1919. For these flights, Byrd invented the bubble sextant which he later used on his polar flights ("Crack Navy Pilots," N.Y. Times, April 10, 1927) and which was planned to be used on the current America project. Interestingly, a derivation of the bubble sextant is still in use today.

Byrd had a prophetic view of the future of aviation and for the importance of his mission to cross the Atlantic:

"For centuries man has trafficked in time and distance. But nature has been a cold bargainer. She conceded grudgingly. It took incalculable centuries to evolve the wheel, and hundred of centuries more to evolve the internal-combustion motor. Within the past century, however, science's knowledge, moving with the accumulating momentum of discovery, has opened up an amazing perspective of time to be lengthened and distances to be diminished" (Murphy, p. 18)

The Folker airplane which was to be used in Byrd's attempt to cross the Atlantic was a modification of the airplane type that Byrd had flown successfully to the North Pole and back. The Fokker America was a monoplane with a wing span of 71 feet and a length of 48 feet. The aircraft was powered by three Wright Whirlwind engines of 220 horsepower each and had a maximum gross weight of 14,500 pounds, which was about two tons heavier than the Fokker aircraft that Byrd had flown to the North Pole. This airplane, however, had a wingspan eight feet longer than that of the polar aircraft to accommodate the extra weight. Much of the weight (7,200 pounds) was fuel. One large fuselage tank, which was actually suspended from the wing above, had an $\mathbf{8 0 0}$ gallon capacity. Four other tanks in the wing held $\mathbf{9 5}$ gallons each and another smaller fuselage tank held 100 more gallons. The large fuselage tank had an emergency dump valve controlled from the cockpit which could empty the tank in less than a minute ("Two Famous Navy Fliers," N.Y. Times, April 10, 1927 p. 25). 


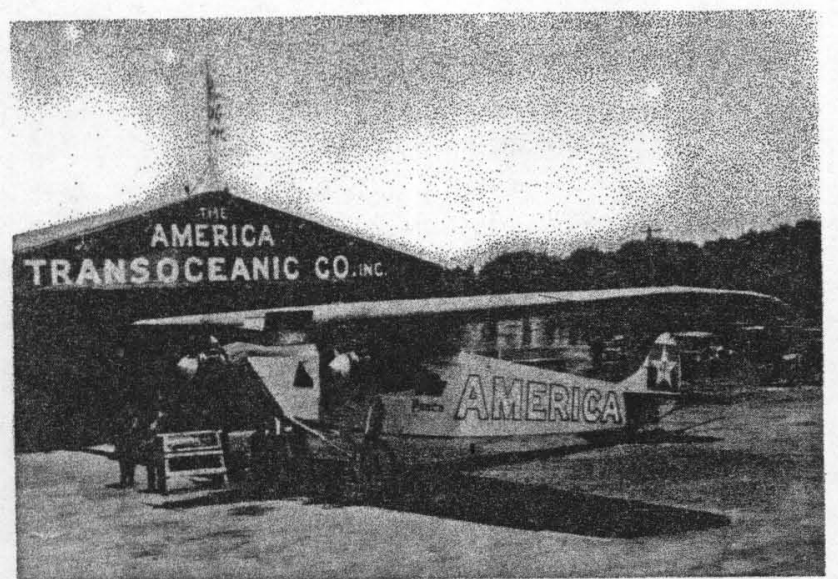

Byrd's Fokker "America"

Photograph: courtesy of Dave Ostrowski Collection

A cat walk connected the fuselage with each engine nacelle which would allow a crew member to reach either of the two outboard engines in flight. A belt fitted with two clamps could be attached to a safety wire that ran to each nacelle which would prevent the brave soul venturing outside from being blown overboard by the ninety mile per hour breeze (Osborne, p. 1082).

The wing of the plane was built at Fokker's plant in Holland while the fuselage was built at the Atlantic Aircraft Corporation in Teterboro, New Jersey, where, also, the complete airplane was assembled (Jablonski, p. 87). The wing was made of wood including the covering which was three-ply veneer plywood, three-thirty seconds of an inch thick (Boiangiu, p. 52). The wing was very strong but proved to have a fatal flaw that would make itself known a few years later. In 1931, a tri-motored Fokker F-10 operated by Transcontinental Air Transport (forerunner of TWA), crashed. The F-10 was a derivative of the Fokker America and shared many of its features. Among those killed in the crash was a famous passenger, Knute Rockne, the great football coach at Notre Dame. This, of course, focused national attention on the Fokker aircraft. While accident investigator fingers pointed in several directions, when all was said and done the cause of the accident was the delamination of the plywood wing skin caused by the accumulation of moisture inside the wing. This defect effectively ended the utility of wooden-wing Fokkers in the United States (Komons, pp. 183-189).

But now it was 1927 and Commander Byrd was in no hurry in his attempt to master the Atlantic. He wanted to fully test the aircraft before setting out. "The tests are as important, in a way, as the flight itself. We want to know exactly what its performance will be under every conceivable condition, so that when we start we may be sure of reaching our objective. I don't like doing things in a hurry," Byrd said (Boiangiu, p. 52). In addition he wanted to provide every safety device possible. The fuselage fuel tank when emptied could provide flotation for the aircraft in case of a ditching. A compartment that contained two rubber rafts, rations, water, and warm, waterproof clothing was included. The survival gear even included a jointed bamboo pole with a red flag attached and a Very pistol with which the unfortunate aviators could signal passing ships should they find themselves in the drink. Also included in the equipment was a radio in which Byrd; operating from a compartment behind the fuselage fuel tank, would work his navigational magic and maintain radio contact with shore facilities as well as surface ships (Boiangiu, p. 52).

For the first test flight of the airplane, which occurred on April 16, 1927, Anthony Fokker himself piloted the airplane. In the right seat was pilot Floyd Bennett who was Byrd's pilot on the polar flight. Standing up behind the pilots and clinging to the pilots' seats were Byrd and Lieutenant George Noville, who was planned to be the alternate pilot for the trip to Paris. With a very light fuel load (only in the wing tanks, none in the large fuselage tank), the plane got off the ground nicely and as long as they could keep the engines throttled up, the plane performed wonderfully. But the instant that power was reduced, the airplane wanted to nose over. On their first landing approach, it was clear to Fokker and Bennett that the airplane was too nose heavy. Applying power without touching down, they made another circuit of the pattern landing hot. On touchdown, when the throttles were reduced to idle, the tail wouldn't come down and continued to rise until the airplane started to nose over. Seeing the inevitable, Fokker cut the switches as the nose plowed into the ground and the nose-engine crushed back into the cockpit. The airplane settled on its back. ("Byrd Plane Crashes," N. Y. Times, April 17, 1927). Fokker escaped unhurt but all of the others sustained injuries. Noville suffered torn stomach muscles, Bennett had a broken leg, and Byrd had broken his left wrist which he set himself on the way to the hospital and after freeing a trapped Bennett from the wreckage (Jablonski, pp. 88, 89).

The relationship between Byrd and Fokker, which 
had not been particularly cordial prior to the accident, worsened considerably. Fokker tried to shift the blame from himself to Byrd (for coming on the test flight) and "even their accounts of the damage to the plane differed" (Jablonski, p. 90). Fokker maintained that the damage was not very extensive (a few panels in the wing punched in, two props bent). He stated that repairs were completed in two weeks. Byrd, on the other hand, said, "The damage to our plane was serious. It took a month of day and night toil to get her back in shape again" (Jablonski, p. 90).

After the plane was repaired, it was positioned at Roosevelt Field, which Byrd had leased for the flight to Paris. With both the Spirit of St. Louis and the Bellanca placed nearby, each waiting for the weather to break, Byrd seemed unconcerned. He had maintained all along that he was not a competitor for the Orteig Prize. In fact, Byrd had not registered for the competition (Boiangiu, p. 53). His purpose, he stated, "is primarily the advancement of aviation" ("Two Famous Navy Fliers," N.Y. Times, April 10,1927, p. 25). In spite of the excitement of the race across the Atlantic building fast in the media, Rodman Wanamaker, Byrd's backer, insisted that Byrd run the America through more tests (Berg, p. 117).

It is no surprise, therefore, that when Lindbergh climbed into the cockpit of the Spirit of St. Louis on May 20,1927, Commander Byrd in a spirit of camaraderie was there to shake his hand (Berg, p. 122) and wish him well. Byrd and the America would later, on June 29, 1927, takeoff from Roosevelt Field and fly to Paris only to be thwarted at the end of the trip by ground fog at (perhaps) Le Bourget field, which prevented a landing. The airplane was ignominiously ditched off the coast of France but at no loss of life (Jablonski, pp. 148-150).

\section{The Keystone Pathfinder}

The announcement by Lieutenant Commander Noel Davis in April, 1927 that his Keystone Pathfinder aircraft was ready for flight stunned the other competitors. The camps of Admiral Byrd and Bellanca, considered by the press to be the only "serious" competitors, had suspected that Davis was not even close to being ready. The "secret of his [Davis'] preparations had been well kept, and the speed with which the plane was put together broke all records for the Keystone factory. . ." ("Two Famous Navy," N.Y. Times, April 10, 1927).

A record, indeed. The three-engine airplane was built in less than six weeks by the Keystone Aircraft Corporation of Bristol, Pennsylvania. The Keystone company evolved from the Huff-Daland company which began manufacturing airplanes in 1920 . Interestingly, Delta Airlines of today can trace its roots to this company through Huff-Daland Dusters of Monroe, Louisiana.

The Keystone Pathfinder aircraft was the derivative of a bomber that was powered originally by 420 hp Liberty V-12 engines. However, for the Orteig competition the aircraft was equipped with three Wright J-5 Whirlwind engines, each producing 220 horsepower. The engines turned metal propellers, unusual for the day when most other propellers were made of wood. Davis' assistant, Navy Lieutenant Stanton $\mathbf{H}$. Wooster, who would share piloting and navigation duties with Davis and who had considerable experience on large airplanes, had insisted on the metal propellers (Naval Aviation News, p. 1).

The aircraft was striking in appearance. Painted a bright yellow, it sported crossed American flags on its fuselage sides, four of them, which flanked the words "American Legion," the name that had been chosen for the machine to honor its sponsors. It was to be the advance guard for the Legion's summer convention in Paris (Boiangiu, p. 56). The 45-foot fuselage was constructed of welded steel tubing and each of its two 67 foot wings was build of fabric-covered wood frame, a traditional method of the day. There were five fuel tanks, three tanks in the upper wing holding a total of 500 gallons, a 100 gallon tank under the pilot's seat and a fuselage tank that held 900 gallons, a total of $\mathbf{1 5 0 0}$ gallons. At full gross weight the airplane would tip the scales at 17,800 pounds (Boiangiu, p. 55). With this amount of fuel, the range of the Keystone was 4,200 miles, 600 more than needed for the trip to Paris.

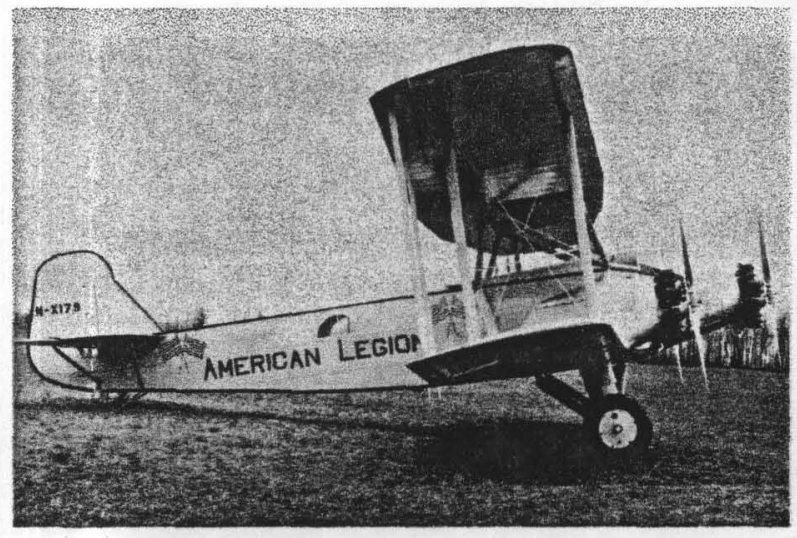

The Keystone Pathfinder

Photograph: courtesy of Dave Ostrowski Collection 
The two-place cockpit was roomy with a throw over control wheel similar to some Bonanzas of today. The navigation and radio compartment was a different story; it was located behind the fuselage fuel tank, which was behind the cockpit and took up all of the room in the fuselage. This meant that to get to the compartment, one of the pilots (Davis) had to go outside the airplane and tiptoe along the fuselage in the wind stream clinging to two tiny handrails while attached to a central wire by a buckle arrangement. The plan was for Davis to do this once an hour to take celestial observations, send radio messages, and hand pump the fuel from the large fuselage tank to the wing tanks ("Davis Plane in Test Flight," N.Y. Times, April 10, 1927).

Incidentally, as absurd as this 'outside of the airplane experience' may seem by today's standards, this was not the first time that provisions had been made for someone to walk around on top of the fuselage. Igor Sikorsky's Ilia Mourometz, a four-engine aircraft produced in Russia in 1914, had an open balcony in the front of the airplane and a platform along the top of the fuselage about fifteen feet behind the upper wing. A staircase led from the cabin to the platform for anyone who wanted to enjoy the $65 \mathrm{MPH}$ breeze. Sikorsky himself had once enjoyed this experience: "Only a few times have I seen such a majestic and beautiful spectacle as I did then... The air was calm and the plane seemed motionless with its huge yellow wings stretched out some twenty feet ahead of where I was standing on the upper platform. All around me was a fairyland, formed by clouds" (Delear, Sikorsky, 1992, pp. $55,56,66)$.

That the Keystone shared the same bright yellow color with the Sikorsky probably mattered little to Davis who was determined to put the airplane through a series of tests to prepare it properly for the long flight. The first flight of the aircraft occurred on April 9, 1927 at Bristol, Pennsylvania and it performed very well with a light fuel load. Davis said, "The plane handles beautifully. . .It shows wonderful maneuverability, but what its actual performance will be I will not know until the tests are completed, a month or six weeks from now. We want to test it thoroughly" ("Davis Plane in Test," N.Y. Times, April 10, 1927).

Davis planned to fly the airplane to Washington D.C. for the installation of some instruments followed by a series of test flights from Langley Field in Virginia. Following the test flights, the Keystone would be flown by
Davis and Wooster to Mitchell Field, New York, the site planned for its launch to Paris.

Several test flights were conducted at Langley Field, each one more heavily loaded than the last. With the vision of the Fonck-Sikorsky crash as a haunting influence, Davis wanted to make sure the Keystone was thoroughly tested (Jablonski, p.90). In each test flight the aircraft performed beautifully. But there was a nagging worry that Davis had expressed to one of his backers, Edwin Wildman, of New York who was a personal representative of Bartlett Arkell, President of Beech Nut Packing Company. Arkell had offered a $\$ 5,000$ supplementary prize to Davis. The airplane was 1,130 pounds heavier than Davis had wanted. Davis had said to Wildman, "This ship is built heavier than we anticipated and that is the reason that I am making all these trial flights and I am taking up an increased load on each flight. Tomorrow morning I shall take a complete load" (Boiangiu, p. 54).

"Tomorrow morning" was April 26" . Davis had ordered a full fuel load for the final test flight. Davis and Wooster were ready. This project had been the brainchild of Davis who was concerned that the planning for the Sikorsky flight the previous year featured an airplane with French engines and flown by a French pilot. His motivation was to "get backing for a flight of his own in an American plane powered with American engines and piloted by Americans" (Boiangiu, p. 56).

Both Noel Davis and Stanton Wooster were graduates of the Naval Academy and each had served in World War I, although the Navy was not a sponsor of this try for the Orteig prize. Davis and Wooster were officially "on leave" for this project.

Wooster climbed into the cockpit first and started the engines on the big bird. Davis made a final walk around and instructed the mechanics to stand at specific points down the field so that he could judge the takeoff distance. With Wooster at the controls, the airplane started moving sluggishly down the runway at Langley Field. It was carrying 9,000 pounds of fuel; its heaviest previous flight had been with 5,000 pounds. About forty seconds into the takeoff run, much longer than was anticipated, the Pathfinder was airborne. Wooster struggled with the airplane and inched it up to about fifty feet but there was a line of trees in front that he was not going to clear. They decided to try and circle hack toward I angley Field, but as the plane was banked to the right, it almost immediately stalled and began to lose altitude. It was obvious that the 
flight could not continue. Working together, Davis and Wooster brought the airplane under control for an emergency landing in the marshes that border the Back River. A little to the right was a tiny peninsula, a strip of green with a pool of water just beyond it. Wooster headed straight for the green marsh. As the plane touched down Davis or Wooster cut the switches to prevent fire. The airplane then skidded for about 125 feet, kicking up mud and water. Then the bird hit the pond and when it reached the other side, it piled up against the bank and turned up on its nose at about a 45 degree angle. The nose was buried in the mud and water. Local Virginia fishermen who were working their nets in Back River witnessed the crash and rushed to the airplane. Disregarding the danger of leaking aviation fizel, they climbed onto the airplane, secured one end of a rope to the tail section and pulled in an effort to right the airplane. The rope snapped. They tried a stronger rope but it also broke. They then attempted to reach the pilots by digging through the mud, but were unsuccessful in saving either Davis or Wooster. Trapped in the cockpit, the two aviators had suffocated Naval Aviation News, p. 2 and Boiangin, pp. 54, 55).

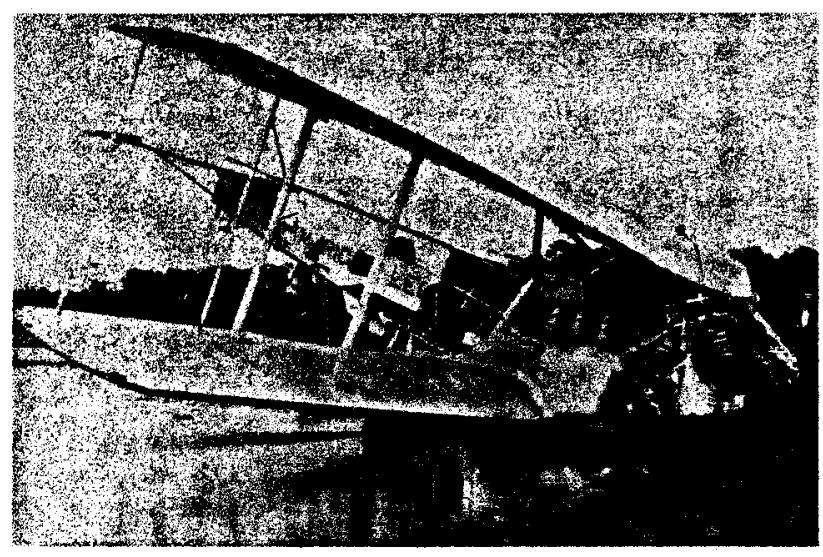

Crash of the Keystone Pathfinder

Photograph: courtesy of Dave Ostrowedci Colloction

The Orteig Prize had now claimed two other aviator's lives and its third three-engine airplane.

\section{The Bellanca}

It is highly probable that the Bellanca aircraft, as a competitor for the Orteig Prize, may well have come about as a result of the actions of Charles Lindbergh. Giuseppe Bellanca had built an airplane for the Wright company as a demonstration vehicle for their new Wright Whirtwind engine. Late in 1926, Lindbergh traveled to New York, met with Bellanca and discussed the airplane. At the time Bellanca was an employee of the Wright company which had no intention of building airplanes. Shortly after he returned to St. Louis from New York, Lindbergh received the word that Wright-Bellanca was not interested in building an airplane capable of crossing the Atlantic. A short time later, Bellanca left the Wright company and established a new company, Columbia Aircraft Corporation backed by an entrepreneur, Charles Levine, who had made his fortune dealing in war-surplus commodities (Jablonski, pp. 100-103). It had been Levine's intention to use the Bellanca aircraft to secure an airmail contract between Chicago and New York (Jablonski, p. 133). The publicity gained from the New York to Paris flight would aid him in those efforts, he felt.

Word came to Lindbergh that Bellanca and the new company would be willing to provide the kind of airplane he was seeking. With a check in hand for $\$ 15,000$, the amount agreed on by Lindbergh and Levine, Lindbergh raced back to New York via the train and met with both Bellanca and Levine. Much to Lindbergh's dismay, Levine said that they could supply the airplane but would insist on choosing the crew. A stunned Lindbergh refused this 'generous' offer. "You are making a mistake," Levine argued; "the Bellanca is the only airplane built that is capable of flying between New York and Paris." To which Lindbergh replied, "I'm sorry, but if you won't sell outright, the sooner I start looking for another plane the better" (Berg, p. 103). Lindbergh then turned his attention to Ryan Airlines and Levine turned his to the Orteig Prize.

The Bellanca, having been christened the Columbia, was a high-wing monoplane with a wingspan of 46 feet 6 inches and a length of 26 feet 9 inches. The wing was constructed of fabric-covered wood and the fuselage was made of welded chrome-molybdenum steel covered with fabric. Fuel for the Wright Whirlwind engine was contained in two piano-shaped fuel tanks housed in the fuselage behind the pilot. The capacity of these tanks was 325 gallons. Fuel from these tanks was pumped by an electric pump to two wing tanks capable of holding 65 gallons which gravity-fed the engine. In case of a pump failure, the airplane was equipped with a hand pump. An extra supply of gasoline was contained in 13 five-gallon cans placed on the shelf of the fuselage tanks. Once fuel was emptied from these cans into the fuselage tanks, the 
cans could be tossed overboard. With fuel, crew, and equipment at the commencement of the planned flight to Paris, the gross weight of the airplane was to be 5,417 pounds ("The Chamberlin-Levine," Current History and Forum pp. 546, 547) (Klemin, "Learning," pp. 72,73).

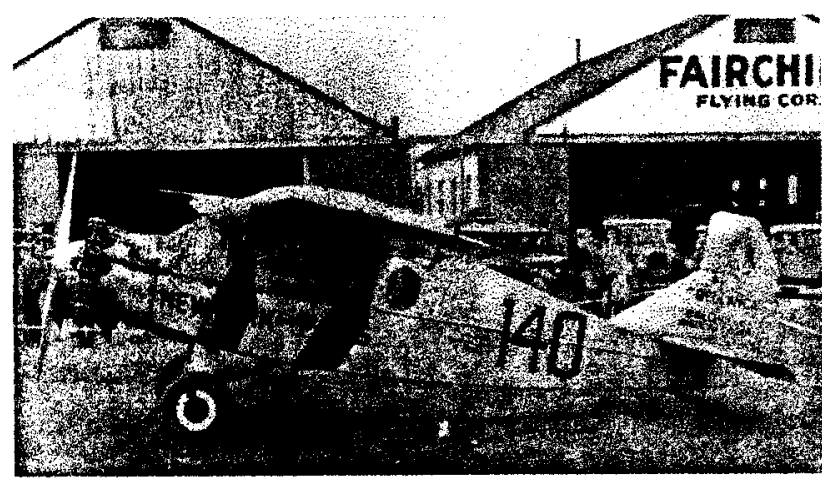

The Bellanca "Columbia"

Photograph: courtesy of Dave Ostrowki Collection

Of all the Orteig Prize contenders, the Bellanca Columbia was the best tested. For example, on April 13, 1927, more than a month before Lindbergh made the Atlantic crossing in the Spirit of St. Louis, Clarence Chamberlin and Bert Acosta set an endurance record of 51 hours, 11 minutes, and 25 seconds. This was clearly a sufficient amount of time to have flown from New York to Paris ("Fifty-One Hours," The Literary Digest, April 30, 1927 , p. 13).

It was not the airplane's capability or performance that kept the Columbia from claiming the Orteig Prize, it was the mishandling of the project by Charles Levine, the owner of the airplane. His constant manipulations led to bickering among the crew and others. Levine wanted to get rid of Clarence Chamberlin, for example, because he was not photogenic. Levine wanted to replace him with someone who would show well in celluloid and newsprint; "his personal relations with pilots was quixotic and the game he played was a kind of aerial musical chairs" (Jablonski, p. 134). With Bert Acosta and Clarence Chamberlin, Levine had two qualified pilots, but he wanted to increase the headline value of the flight by making a game of selecting the pilot. The N.Y. Times ("Mail Flyer Chosen") quoted Levine as saying, "The choice will not be made until the last minute before the flight, and it will then be determined by lot. Both pilots will appear on the field in flying togs. Their names will be written separately on slips of paper. One slip will be drawn. The name on it will decide the flyer."

This was neither the first nor the last time Levine hacked off the players with such shenamigans. The names of potential fliers appeared and disappeared with regularity. But at last it seemed settled. It would be Chamberlin as pilot and Lloyd Bertaud, an experienced airmail pilot and navigator, as pilot/navigator. It was not a match made in heaven. Chamberlin and Bertaud had significant disagreements as how the flight was to be conducted and what equipment should be carried on board. Bertaud wanted to carry a radio, for example, while Chamberlin regarded it as so much dead weight.

In late April the airplane was damaged when a pin was sheared on a shock absorber and a landing was made with a dangling and useless left landing gear. The damage was minor, however, and the airplane was quickty repaired. It was easier to fix airplane problems than ego problems and as the Bellanca team bickered, time melted away.

Soon it was May. Then in mid-May on the eve of the planned flight, Levine presented a contract to both Chamberlin and Bertaud that essentially put them on a small salary and brought to Levine all of the proceeds, of which there would be about $\$ 75,000$ in addition to the $\$ 25,000$ Orteig prize (for which they were technically ineligible because of having missed the filing deadline as did Lindbergh). Initially both the pilots signed the contract, then Bertaud, after thinking it over, got a lawyer who filed a temporary injunction against Levine which restrained him from allowing the commencement of the Paris flight until the contract issues were resolved. Meanwhile, Lindbergh had flown into Roosevelt Field and was waiting for a break in the weather. Also, Byrd's entourage had returned with a repaired airplane. By the time the injunction was dismissed on the Bellanca, it was May 20, Lindbergh had taken off and was over Nova Scotia winging his way to Paris. Ironically, the Bellanca was ready to go and could have taken off a week earlier but it was Friday the $13^{\text {th }}$ and the superstitious Levine did not want to begin the flight on that day. When the Bellanca did take off for Europe less than a month later, on June 4, with Chamberlin and Levine (!) in the cockpit, it crossed the Atlantic successfully and flew all the way to a point just short of Berlin (Jablonski, pp. 133-142).

The Levasseur PL-8 "White Bird"

After the crash of Rene Fonck's Sikorsky S-35 on September 21, 1926, Fonck ordered another Sikorsky to try 
again in September, 1927. But Fonck was not France's only hope of winning the competition. At one point there were at least five French teams in the chase ("French Speed Plan," N.Y. Times, April 16, 1927). One of those teams was Captain Charles Nungesser and Lieutenant Francois Coli. Known as the "one-eyed navigator" because of the sinister patch he wore over one eye, Coli was involved with two projects. It had long been his desire to fly non-stop from Paris to New York. His other teammate was another French pilot, Lieutenant Tarascon. They had ordered a plane for the crossing but it was not to be ready before August 1927. Nungesser's Levasseur airplane was going to be ready much sooner. Coli withdrew from the relationship with Tarascon and concentrated on the Nungesser effort ("French Pledge Aid," N.Y. Times, April 1, 1927).

Both Nungesser and Coli had seen action in World War I and like Fonck, Nungesser was a national hero. He was the most highly decorated Allied pilot and ranked third among French aces, having shot down 45 enemy aircraft (Project Midnight Ghost, p. 12).

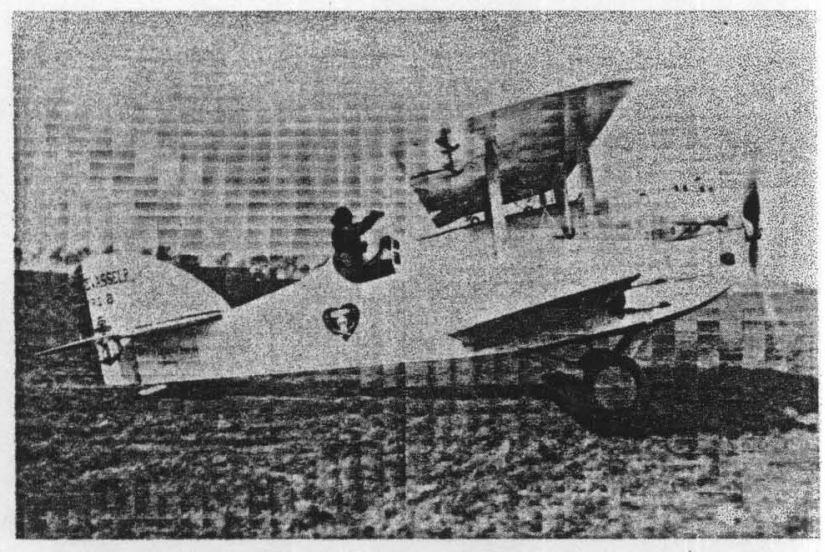

The Levasseur PL8 "White bird"

Photograph: courtesy of Dave Ostrowski Collection

The aircraft, a Levasseur PL-8 biplane, long range aircraft, was derived from the Levasseur Marin (marine) PL-4, a three-place airplane constructed for the French Navy. The name "marin" was given because of its unique construction. The hull looked much like a seaplane and the cockpit area was watertight. The crew could drop the PL4's landing gear, land on the ocean, and float for a long time (presumably until help came, for it was incapable of taking off from the water). As with its predecessor, the PL8 had a jettsionable landing gear which, once jettisoned, reduced its weight by 270 pounds and made the airframe much more efficient. It was Nunguesser and Coli's intention to drop the landing gear shortly after takeoff and splash down in New York harbor some thirty odd hours later (Meunier, p. 5).

The airplane was 31.8 feet long with a wingspan of 47.9 feet. Both wings were of the same length. The pilot and navigator sat about seventeen feet from the nose of the airplane in an open cockpit. The pilot sat to the left while the navigator's area was to the right, slightly below and slightly aft. Between the crew and the nose of the airplane were three fuel tanks mounted one behind the other that held some 1,063 gallons (approximately 6,378 pounds) (Project Midnight Ghost, pp. 28, 29).

The maximum gross weight of the airplane was 11,089 pounds. At the business end of the airplane was a twelve-cylinder, liquid-cooled, Lorraine-Dietrich engine in a " $W$ " configuration. This was a well-known type of engine that had seen reliable service on other airplane types. It was rated at 450 horsepower nominally with a maximum rating of 525 horsepower. Fuel consumption at 1900 RPM (nominal for $450 \mathrm{hp}$ ) ranged from 213 to 264 pounds per hour (Meunier, pp. 6, 7).

The airplane was tested for 22 days, from April 15 to May 6, 1927. None of the test flights were made with the aircraft at maximum weight. "Nungesser's reason for this is that he knew quite well the major risk that such a takeoff implied, and that because of this preferred only to run the risk once" (Menuier, p. 8). For the first nine days, the testing was done with a Lorraine Dietrich engine of the same type but not the one that was to be used for the flight to New York. For that, a new engine was undergoing tests at the factory. It was to be installed and tested to Nungesser's satisfaction before the Atlantic flight ("Nungesser Hopes to Fly," N.Y. Times, April 21, 1927 ).

The aircraft was painted a brilliant white thus spawning the name L'Oiseau Blanc (White Bird). Painted on the side of the fuselage just below and aft of the cockpit was a large black heart, inside of which, painted in white, were a skull and crossbones with a coffin laid out horizontally just above the skull. It was the same emblem that Nungesser had carried into combat many times during World War I. "The idea is that a strong heart doesn't fear death, even in it's most terrible aspects," Nungesser explained ("Nungesser Hopes to Fly," N.Y. Times, April 21, 1927).

On the morning of May 8,1927, Nungesser and 
Coli made their arrival at le Bourget airfield in an open touring car and were greeted by a large crowd. A girl tossed a rose, which Nungesser caught, rewarding her by blowing a kiss (Jablonski, pp 94, 95). Final words were shared with friends then the crew entered the cockpit of the White Bird. The engine was started at 5:15 a.m. and three minutes later, the aircraft was on its takeoff roll at a gross weight of 4,864 kilograms ( $(10,723$ pounds). More than 6,000 pounds of that weight was in fuel. It is not known for certain how much fuel the tanks contained for the flight. An analysis of the known facts places the estimate at 3800 liters (1003 gallons) or about 40 hours of flight time (Meunier, pp. 15, 16).

The plane rumbled heavily down the runway picking up speed. It lifted sluggishly, settled back down, rose again clumsily then bounced back to the nunway. The plane lifted again for the third time and remained barely aloft (Jablosnki, p. 93). This marked the first time that a contender for the Orteig Prize had actually become airborne. The takeoff had consumed 47 seconds and 2,950 feet (Meunier, p. 16).

Near the French coast Nungesser released the landing gear. Several sightings of the White Bird occurred, the last being over the Irish coast with the aircraft heading westward, out to sea. Then Nungesser and Coli disappeared into the mist of the Atlantic and were never seen again. Lindbergh, in his Pulitzer Prize winning book, The Spirit of St. Louis (p. 130) describes it thusly. “It's May $9^{\text {th }}$. Step by step newspaper headlines have followed Nungesser and Coli from their take-off at Paris to the city of Boston, only to have them vanish like midnight ghosts."

The news reports moved peoples' emotions up and down the scale from hope to despair. But, finally, the gloomy fact settled in that these brave flyers were gone.
The Lost Fliers - Nungesser and Coli By Isabelle Elling

I heard the motors roar, I saw the takeoff and the rise;

I felt the rush of wind beneath the wings

And upward raised my eyes. ...

You cleft the clouds. . you rode the trackless air-

A strange and shining star.

A meteor shot from the fields of France

To span a distant shore.

.. I dropped my head to cup my hands against my eyes.

'Tis a moment all my life

I shall be sorry for! !

For in that moment you had left the world and me.

And though I heard a faint hum

Drifting from those hills of mist And though I strained my eyes through tears

To film a glimpse of you

I could not see. . .

I knew that you were gone.

. . All my days I shall be listening now. Heart-startled with every plane I hear. With every little sound like engines from afar.

But always, it is just a gust of wind... Or the throbbing of the Sphinx-like sea Beneath a lonely and impervious sky.

(Elling, Isabelle. The Literary Digest, July 16, 1927, p. 32) 
To this day, mystery and intrigue surround the disappearance of the White Bird and people still search. For example, the International Group for Historic Aircraft Recovery (TIGHAR) have an ongoing effort called Project Midnight Ghost. Within the last decade, this group has searched in Newfoundland and in Maine for evidence of the White Bird. But like the circumstances surrounding the disappearance of Amelia Earhart, the evidence is inconclusive and the mystery remains.

The Ryan "Spirit of St. Louis"

While this article is primarily about the other competitors for the Orteig Prize, certainly in a comparative analysis such as this, we would be remiss to ignore Charles $\mathbf{A}$. Lindbergh and the Spirit of St. Louis.

The aircraft selected for the flight was a special modification of the Ryan M-2 Mail plane design, a monoplane. The Ryan company was not the first choice. Lindbergh, having conceived of the flight on a mail run from St. Louis to Chicago, contacted several manufacturers: Fokker, Wright, Bellanca, and Ryan. His first choice was the Wright-Bellanca aircraft and was set to close the deal with check in hand when the company refused to sell the airplane unless they could select the crew. This was an unacceptable condition to Lindbergh. He then turned to the Ryan Airline Company of San Diego. He was on scene during the entire time of the design and construction of the airplane and provided advice and direction on many of its design elements. He also tested the airplane and, at the time of the Atlantic crossing, was the only pilot to have flown it (Lindbergh, The Spirit of St. Louis, 1953, pp. 3-178).

The final configuration of the airplane was a wingspan of 46 feet (an increase of 10 feet from the standard M-2), a length of $27+$ feet, and powered by a 220 horsepower Wright J-5 Whirlwind engine. The fuselage was constructed of welded carbon-steel tubes and the wing was made of spruce ribs and spars braced with piano wire. "-wing, fuselage, tail section, external struts (the wings' supports), axles, and tail skid - was covered with Grade A cotton fabric finished with cellulose acetate dope, in silvergray" (Berg, p. 110). Fuel was contained in several tanks: a main fuselage tank containing 200 gallons located under the wing, three wing tanks containing 145 gallons, and a nose (forward fuselage tank containing 80 gallons. This adds up to 425 gallons but was increased by 25 gallons to 450 gallons when flight testing revealed that less oil could be carried than originally planned, thus providing a weight allowance of another 25 gallons of fuel (Lindbergh, The
Spirit of St. Louis, 1953, pp. 531-540). Lindbergh was judicious in his pursuit of saving weight. He even trimmed his maps so that no unnecessary paper would add to the total weight. Less weight meant a shorter takeoff run, lower fuel consumption en route, and a greater range or fuel reserve.

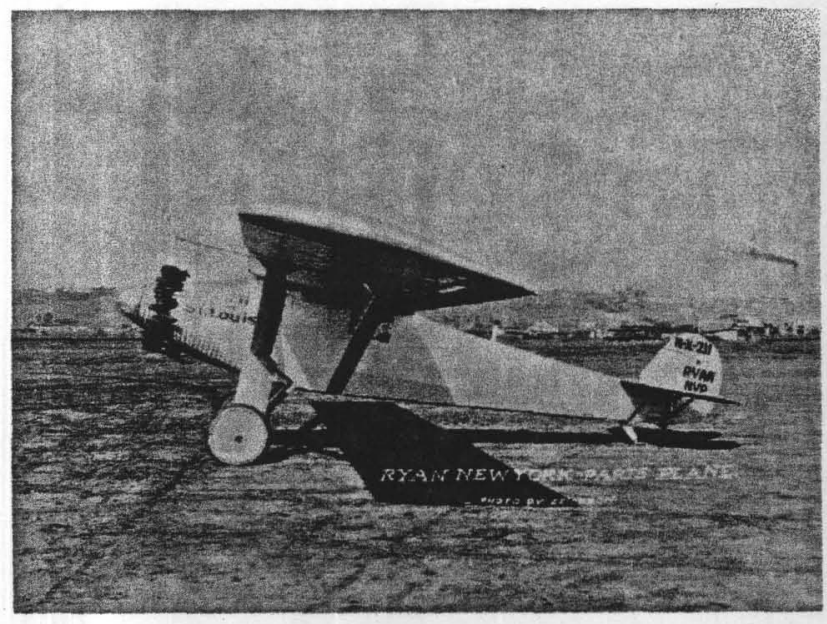

Ryan Airlines Spirit of St. Louis

The cockpit was located directly behind the main fuselage fuel tank and behind the wing. At Lindbergh's insistence, no provision was made for a forward-looking windshield. It was an unnecessary luxury and Lindbergh was accustomed to flying airplanes with little forward visibility during ground operations and some flight elements. The cockpit was located so far back on the modified war-surplus DH-4 aircraft, which Lindbergh was accustomed to flying on mail runs, that it was impossible to see directly ahead of the airplane on takeoff until the tail was raised. For the Spirit of St. Louis, view out the side windows plus a small periscope device that gave him a restricted forward view were sufficient. Also, one of the reasons for placement of the cockpit in such as position was to minimize injury to the pilot in the event of a nose-over crash landing (Jablonski, p. 106).

The plane was completed in exactly sixty days after work began, designed for a maximum gross weight of 5,000 pounds and a range of 4,000 miles. During the entire time of the construction of the airplane, Lindbergh was uncertain, perhaps wary, of his chances. "He read about Byrd, Davis and Nungessr, wondering if he himself would 
ever get to fly the Atlantic. He read of the great endurance flight in Levine's Bellanca. . . Then came the more dismal reports of Byrd's crash, the wiping out of the Bellanca's landing gear, the deaths of Davis and Wooster" (Jablonski, p. 105). When Nungesser and Coli departed Paris, Lindbergh was ready to fly the Spirit of St. Louis to St. Louis but weather held him on the ground. So convinced that these two airman would be successful, he considered changing his plans for a Pacific flight. By the time the weather cleared, on May 10, Nungesser and Coli were missing and Lindbergh was on his way to St. Louis. He stopped there overnight, having broken a record enroute, and continued on to New York. On arrival, two other competitors were poised to fly, Byrd in the Fokker, and Chamberlin in the Bellanca. Lindbergh arrived in New York on May $12^{\text {th }}$ and could have been ready to go in a day or so, but bad weather held him back. Then on the evening of May $19^{\text {th}}$, the weather reports looked favorable and Lindbergh decided to make a try at it on the morning of May 20. Arriving at the airport, he was surprised at the lack of activity at the other two camps. At 7:54 a.m., the Spirit of St. Louis was airborne and heading for Paris. "The story of that takeoff has been told and retold: how the overloaded plane struggled to break free of the mud, moving slowly at first, then gaining speed; how it splashed through the puddles, lifting from the ground at the 2,000 foot mark, but sinking again, lifting for a second time at 3,000 feet, then once more settling back; up finally at 4,200 feet with only 800 feet remaining. . ." (Delear, Famous First Flights, 1979, p. 98).

Why was Lindbergh more successful than the final three competitors for the Prize? All had capable pilots and all had capable aircraft. One conclusion, perhaps the correct one, was provided by Lindbergh himself:

"With every day that passes here in New York, I realize more fully that, aside from a plane with performance enough to make the flight, my greatest asset lies in the character of my partners in St. Louis. Byrd has been delayed by elaborate organization, and by Wanamaker's cautious insistence on a 'scientific' test program for the America. Bitter dissention has broken out in the Bellanca camp; there are still arguments about who is to go, the route to be followed and whether or not to carry a radio along. . .and Bertrand has obtained a court injunction to restrain the airplane from taking off without him. . But my partners have not interfered with my plans in any way. They've stuck to [the] original proposition that they'll take care of the finances, and leave the technical end of the flight to me" (Lindbergh, The Spirit of St. Louis, 1953, p.169).

It was the successful formula.

But, technically, Lindbergh had not won the Orteig Prize. The crush of time had prevented him from providing the sixty-day advance notice required by the rules. However, on Mr. Orteig's request, the sixty-day advance notice "was waived by the Trustees of the Prize fund, and the prize was officially awarded to Col. Lindbergh on June 16, 1927, at Hotel Brevoort, New York City" (Lindbergh, The Spirit of St. Louis, 1953, p. 530).

One final note about Lindbergh that speaks to the man's humanity and concern for his fellow aviators and competitors for the Prize. Lindbergh made it a point to visit Nungesser's mother who, after the disappearance of her son, had been understandably critical of the wisdom of trying to conquer the Atlantic. Lindbergh did his best to provide her comfort and eulogize the sacrifice her son had made for the progress of aviation ("What Nungesser's Mother Thinks," The Literary Digest, May 12, 1928, pp. 69-71).

Tim Brady holds a Ph.D. in Higher Education Administration from Saint Louis University, a Master of Science Degree from Abilene Christian University, and a Bachelor of Science Degree from Troy State University. He is currently the Dean of the School of Aviation at Embry-Riddle Aeronautical University in Daytona Beach, Florida. He also serves on the Board of Trustees of the Council on Aviation Accreditation and is the Chairman of its Accreditation Committee. He is dual rated as a pilot and navigator and holds the Air Transport Pilot (ATP) rating. 


\section{REFERENCES}

1,550-Mile Flight Made by Lindbergh. The New York Times, May 12, 1927, p. 25, Col. 4.

Aircraft Yearbook - 1927, New York, Aeronautical Chamber of Commerce of America, Inc., 1927.

Airman Cleared by Speedy Inquiry. The New York Times, September 22, 1926, p. 4, Col. 2.

Airmen Here Sorry French Aces Failed. The New York Times, May 10, 1927, p. 4, Col. 3.

A Projected Transatlantic Flight. Scientific American, Vol. 135, August, 1926, pp. 146-148.

A Salute to Rodman Wanamaker. www.wanamakerorgan.com/rodman.html (on line), pp. 1-7.

Bellanca's Transatlantic Preparations. Scientific American, Vol. 137, July, 1927, 72-73.

Bellanca Plane Ready in Six Days. The New York Times, April 30, 1927, p.2, Col. 1.

Berg, A. Scott. Lindbergh, New York, G. P. Putnam's Sons, 1998.

Boiangiu, Suri \& Keylin, Arleen, editors. Flight, as Reported by the New York Times, New York, Arno Press, 1977.

Brady, Tim. The American Aviation Experience: A History, Carbondale, IL., Southern Ilinois University Press, 2000.

Brown, Carl A. A History of Aviation, Daytona Beach, Embry-Riddle Aeronautical University, 1980.

Byrd's Plane Crashes.... The New York Times, April 17, 1927, p. 1, Col. 1.

Congress Side-Tracking Aviation. The Literary Digest, Vol. 62, July 26, 1919, 15-16.

Crack Navy Pilots to Man Both Airplanes. The New York Times, April 10, 1927, p. 1, Col. 2.

Dargue Sees Hope for French Fliers. The New York Times, May 12, 1927, p. 2, Col. 4.

Davis Plane in Test Flight. The New York Times, May 10, 1927, p. 4, Col. 3.

Delear, Frank J. Famous First Flight Across the Atlantic, New York, Dodd, Mead \& Company, 1979.

Delear, Frank J. Igor Sikorsky - His Three Careers in Aviation, New York, Bantam Books, 1992.

Elling, Isabelle. The Lost Fliers - Nungesser and Coli (a poem). The Literary Digest, Vol. 94, July 16, 1927, p. 32.

Feel Paris Flight Will Soon Be Made. The New York Times, May 31, 1919, p. 2, Col. 2.

Fifty-One Hours in the Air. The Literary Digest, Vol. 93, April 30, 1927, p. 13.

Fliers in Both Airplanes Will Report to The New York Times. The New York Times, May 10, 1927, p. 4, Col. 3. p. 1, Col. 1.

Fonck Plane Burns, 2 Die at Start of Paris Flight; Ace and Curtin Escape. The New York Times, September 22, 1926, 
Fonck's Flight Plans Raise More Discord. The New York Times, August 29, 1926, p. 2, Col. 6.

Fonck's Plane Beautified. The New York Times, July 28, 1926, p. 19, Col. 1.

Fonck's Plane to Carry Hot Dinner to Paris; To Be Eaten at Celebration of Ocean Hop. The New York Times, August 16, 1926, p. 1, Col. 2.

Col. 5.

French Pilots Ask Levasseur to Back Another Paris-New York Venture. The New York Times, May 19, 1927, p. 2 ,

French Pledge Aid to Atlantic Flight. The New York Times, April 1, 1927, p. 25, Col. 4.

French Still Cling to Hópe for Fliers. The New York Times, May 12, 1927, p. 2, Col. 7.

French Speed Plan to Make Hop First. The New York Times, April 16, 1927, p. 3, Col. 6 et, al, (this issue contains a summary of current transatlantic efforts).

Fruenthal, Elsbeth E., The Aviation Business, New York, Vanguard Press, 1940.

Gardner, Lester D., An American Expert Replies (to Is Aviation a Delusion?). American Review of Reviews, Vol. 76, July, 1927, 42-44. 551-555.

Halsey, Courtney W., Notable Episodes in the History of Flying. Current History and Forum, Vol. 26, July 27, 1927,

Hinton, Walter, Lieutenant., The First Transatlantic Flight. Current History and Forum, Vol. 26, July 27, 1927, 548-

Hunt Hidden Flaws on the Bellanca. The New York Times, May 12, 1927, p. 2, Col. 5.

Igor Sikorsky Historical Archives. Www.sikorsky.com/about/history.html, pp. 1-3.

Insley, Robert, Air-Cooled Engines for Aircraft. Scientific American, Vol. 137, August, 1927, 148-151, 182.

Is Aviation a Delusion? American Review of Reviews, Vol. 76, July, 1927, 39-41.

Jablonski, Edward. Atlantic Fever, New York, The MacMillan Co., 1972.

Klemin, Alexander. Byrd and the "America." Scientific American, Vol. 137, September, 1927, 256-258.

Klemin, Alexander. Learning to Use Our Wings. Scientific American, Vol. 137, July, 1927, 72-73.

Klemin, Alexander. Lindbergh's Transatlantic Flight. Scientific American, Vol. 137, August, 1927, 167-169.

Komons, Nick A. Bonfires to Beacons, Washington, D. C., Smithsonian Institution Press, 1989.

Lindbergh, Charles A. We, New York, G. P. Putnam's Sons, 1927.

Lindbergh, Charles A. The Spirit of St Louis, New York, Charles Scribner's Sons, 1953.

Mail Flier Chosen for Bellanca Hop. The New York Times, April 20, 1927, p. 11, Col. 2. 
4.

Message From Nungesser and Coli Tells of Sorrow at Davis's Death. The New York Times, May 12, 1927, p. 25, Col.

Meunier, Clement-Pascal (translated by Patricia R. Thrasher). Nungesser \& Coli Disappear Aboard the White Bird. May 1927, Wilmington, DE, The International Group for Historic Aircraft Recovery (TIGHAR), 1960.

Miller, F. T. The World in the Air (Volume II), New York, G. P. Putnam's Sons, 1930.

Motor Vehicle Production, U.S. and Canada. Automotive Industries, Vol. 68, February 18, 1933, p. 219.

Murphy, Charles J. V., The Flight of the America. Colliers, Vol. 82, April, 1928, 17-18.

Naval Aviation News. www.history.navy.mil/nan/1999/marapr99/dare.htm, (on line), pp. 1-3.

New York-Paris Flight a Reality. Aviation, Vol. 22, May 30, 1927, 1120-1122.

Nungesser and Coli Missing in Atlantic Flight Attempt. Aviation. Vol. 22, May 16, 1927, 1041-1042.

Nungesser Hopes to Fly in Ten Days. The New York Times, April 21,1927, p. 29 Col. 1.

On the Proposed Trans-Atlantic Flight. Aviation, August 23, 1926, 318-319.

Orteig Expresses Regret. The New York Times, April 28, 1927, p. 25, Col. 3.

Osborne, Robert. R, On the Atlantic Flight Preparations. Aviation, Vol. 22, May 23, 1927, 1082-1084.

Paris Lays Bets on Ocean Flights. The New York Times, April 23, 1927, p.19, Col. 2.

Peace Announced for Fonck's Flight. The New York Times, September 7, 1926, p. 17, Col. 1.

Plans Progress for Trans-Atlantic Flight. Aviation, Vol. 22, May 9, 1927, 98-99.

Proiect Midnight Ghost (Writings from TIGHAR Tracts, 1985-1992). Wilmington, DE, The International Group for Historic Aircraft Recovery (TIGHAR), 1997.

Puts Up \$25,000 for Paris Flight. The New York Times, May 30, 1919, p.1, Col. 2.

Small Airplanes and the Trans-Atlantic Flight. Scientific American, Vol. 120, April 26, 1919, p. 427.

Ross, Walter S. The Last Hero: Charles A. Lindbergh, New York, Harper and Row, Publishers, 1968.

The Air Not Yet Conquered. The Literary Digest, Vol. 94, June 16, 1927, 5-7.

547.

The Chamberlin-Levine Flight From America to Germany. Current History and Forum, Vol. 26, July 27, 1927, $543-$

The Non-Stop Trans-Atlantic Flight. Scientific American, Vol. 120, June 21, 1919, 656-657.

Tryout of Fonck's Plane. The New York Times, August 7, 1926, p. 26, Col. 4.

Two Famous Navy Fliers. . .Story of Byrd's Plans. The New York Times, April 10, 1927, p. 1, Col. 1, p 25, Col 1. 
Wade Quits, Calls Paris Hop Untimely. The New York Times, April 9, 1927, p. 21, Col. 4.

What Nungesser's Mother Thinks of Ocean Flights. The Literary Digest, Vol. 97, May 12, 1928, 69-71. 
